\title{
Flor Yeast Proteomic Response to the Lack of Fermentable Carbon Source
}

\author{
Jaime MORENO-GARCÍA ${ }^{1)}$, Georgiana-Diana DUMITRIU'), Juan MORENO ${ }^{3)}$, M. Carmen MILLÁN ${ }^{1)}$, Juan \\ Carlos MAURICIO ${ }^{1)}$, Teresa GARCÍA-MARTÍNEZ ${ }^{1)}$ \\ ${ }^{1)}$ Department of Microbiology, Severo Ochoa (C6) building, Agrifood Campus of International \\ Excellence ceiA3, University of Cordoba, 14014, Cordoba, Spain \\ ${ }^{2)}$ University of Agricultural Sciences and Veterinary Medicine, 700490, Iasi, Romania; \\ ${ }^{3)}$ Department of Agricultural Chemistry, Marie Curie (C3) building, Agrifood Campus of International \\ Excellence ceiA3, University of Cordoba., 14014, Cordoba, Spain \\ ${ }^{*}$ Corresponding author, e-mail: dumitriu.diana22@yahoo.com
}

Bulletin UASVM Horticulture 72(1) / 2015

Print ISSN 1843-5254, Electronic ISSN 1843-5394

Doi:10.15835/buasvmcn-hort:10322

\begin{abstract}
Flor yeasts metabolism highly configures organoleptic properties in Sherry type wines during biological aging (Peinado et al., 2009). Along this process, the mentioned yeasts prevail by forming a biofilm in the wine surface and the presence of certain proteins involved in the response to stresses becomes essential for survival, among the most important ones: lack of fermentable carbon sources. The main aim of this study is to compare proteome data from the flor yeast Saccharomyces cerevisiae G1 in a typical biological aging condition (without fermentable carbon source) and in a fermentative condition (with fermentable carbon source). In this work, OFFGEL fractionator coupled to LTQ Orbitrap XL MS equipment were used trying to identify the maximum possible number of proteins related to the lack of fermentable carbon source stress in a synthetic biological aging and under a reference fermentative condition. As a result, 18 stress proteins responding to the lack of fermentable carbon source have been detected only in the biological aging condition or higher than in the reference condition which are involved in biofilm formation, perception of stimuli among other biological processes. This study together with other experiments that definitively confirm the necessity of these proteins synthesis, may lead to the genetic improvement of flor yeast strains aimed to enhance their survival during the biological aging process and hence the whole wine elaboration process.
\end{abstract}

Keywords: Flor yeast, lack of fermentable carbon source, proteome.

\section{INTRODUCTION}

Sherry is a fortified wine made from white grapes that are grown near the town of Jerez de la Frontera in Andalucía, Spain; but also produced in other areas worldwide. It is characterized by a specific color, texture, flavour and taste; consequence of a process known as "Biological Aging" which is carried out during the wine elaboration procedure after the must fermentation. Along this and because of the metabolism performed by a special type of biofilmforming yeast strain, so-called flor yeast, ethanol and glycerol are consumed while other chemicals, like acetaldehyde or acetic acid, are produced (Peinado and Mauricio, 2009).

Flor yeasts have to face several harsh conditions for survival (Alexandre, 2013). One of the principal is the lack of a fermentable carbon sources like glucose or fructose already consumed during the previous fermentation process. Zara et al., (2010) considered the formation of the biofilm (also called "flor" or "velum") an adaptation system of the flor yeast to a medium which lacks a fermentable carbon source. Biofilm formation in the wine-air area allows the yeast to reach an 
oxygen-rich zone where it is possible to catalyze ethanol or glycerol, both produced in fermentation.

Until now, genes that codify stress response proteins have been used as targets for the genetic improvement of wine yeast strains to enhance the fermentation performance (Pretorius et al., 2002) although their use in the wine production is forbidden almost in totality. Also, in the biological aging process, a higher quality in velum and a higher cell viability have been attained by the overexpression of response to stress genes (Fidalgo et al. 2006; Zara et al. 2009; Fierro-Risco et al., 2013).

In order to detect proteins related with the flor yeast response to a medium without a fermentable carbon source, a proteome analysis have been carried out from a flor yeast strain grown in a biological aging condition (BAC) without fermentable carbon source, and in a reference fermentative condition (RFC) (with fermentable carbon source) for comparison and a database search has been performed in order to detect proteins involved in the response to lack of fermentable carbon source.

\section{MATERIALS AND METHODS}

Flor yeast Saccharomyces cerevisiae G1 strain (ATCC: MYA-2451), was used in this work. A population of $1 \times 10^{6}$ cells $/ \mathrm{mL}$ was inoculated in a biofilm formation medium or BAC $(0,67 \%$ $(\mathrm{w} / \mathrm{v})$ YNB without amino acids (Difco), 1\% w/v glycerol, $10 \mathrm{mM}$ of glutamic acid and $10 \%(\mathrm{v} / \mathrm{v})$ ethanol added after sterilization, without shaking during 29 days) and in the non-biofilm formation medium or RFC $(0,67 \%$ (w/v) YNB without amino acids (Difco), $17 \%$ glucose and $10 \mathrm{mM}$ of glutamic acid shacking during 12 hours). The process was carried out at $21^{\circ} \mathrm{C}$. All media were autoclaved at $12{ }^{\circ} \mathrm{C}$ for 20 minutes. Cells from the biofilm were harvested by suction and from the non-biofilm culture by centrifugation both in an initial phase when the cell viability was higher than $90 \%$. The resulting cellular pellet from each condition was resuspended in $1 \mathrm{~mL}$ extraction buffer supplemented with Protease Inhibitor Cocktail tablets, and cell wall was broken by vortexing in a Vibrogen Cell Mill. Glass beads as well as cell debris were discarded by centrifugation. Protein precipitation was carried out by overnight incubation at $-20{ }^{\circ} \mathrm{C}$ after addition of $10 \% \mathrm{w} / \mathrm{v}$ of trichloroacetic acid (TCA) and 4 volumes of ice- cold acetone to the supernatant. After incubation, samples were centrifuged and the protein pellet was vacuum dried and then resuspended in solubilization buffer (8 $\mathrm{M}$ urea, $2 \mathrm{M}$ thiourea, 4\% CHAPS and 1\% DTT). Protein concentration was estimated by Bradford assay (1976) and samples stored at $-80^{\circ} \mathrm{C}$ until proteins analysis.

The OFFGEL High Resolution kit pH 3-10 was used for protein preparative isoelectric focusing (IEF) in solution. Protein samples (450 $\pm 50 \mu \mathrm{g})$ were solubilized in Protein OFFGEL fractionation buffer, glycerol, and buffer with ampholytes and aliquots evenly distributed in a 12-well 3100 OFFGEL Fractionator tray. Preset program OG12PR00 separation limits were used following recommendations of the manufacturer: $4500 \mathrm{~V}$, $200 \mathrm{~mW}$, and $50 \mu \mathrm{A}$; starting voltage, 200-1500 V; ending voltage, 5000-8000 V; after the application of $20 \mathrm{kVh}$, the protein separation zones were maintained at constant voltage. Peptides from each well were scanned and fragmented with the LTQ Orbitrap XL mass spectrometer equipped with a nano LC Ultimate 3000 system. The electrospray voltage was set to $1300 \mathrm{~V}$ and the capillary voltage to $50 \mathrm{~V}$ at $190 \mathrm{Co}$. The LTQ Orbitrap was operated in the parallel mode, allowing for the accurate measurement of the precursor survey scan $(400-1500 \mathrm{~m} / \mathrm{z})$ in the Orbitrap selection, a 60000 full-width at half-maximum (FWHM) resolution at $\mathrm{m} / \mathrm{z} 400$ concurrent with the acquisition of three CID Data-Dependent MS/MS scans in the LIT for peptide sequence, followed by three Data-Dependent HCD MS/MS scans $(100-2000 \mathrm{~m} / \mathrm{z})$ with $7500 \mathrm{FWHM}$ resolution at $\mathrm{m} / \mathrm{z} 400$ for peptide sequence and quantification. The normalized collision energies used were $40 \%$ for HCD and $35 \%$ for CID. The maximum injection times for MS and MS/MS were set to $50 \mathrm{~ms}$ and $500 \mathrm{~ms}$, respectively. The precursor isolation width was $3 \mathrm{Da}$ and the exclusion mass width was set to $5 \mathrm{ppm}$. Monoisotopic precursor selection was allowed and singly charged species were excluded. The minimum intensity threshold for MS/MS was 500 counts for the linear ion trap and 8000 counts for the Orbitrap. Database search was performed with Proteome Discoverer 1.0 (Thermo Fisher Scientific software, San José, CA. USA) against Uniprot including fixed modification Carbamidomethylation in Cys and proteome results were statistically analyzed with the Proteome Discoverer software. 
After identification, proteins related to the response to biological aging stress lack of fermentable carbon source were selected from both conditions attending to mutant phenotypes, gene ontology terms (GO Terms) or references using YeastMine tool from SGD and Uniprot databases.

To compare quantity of proteins detected in both conditions, a relative quantification has been carried by using the exponentially modified protein abundance index or emPAI (Ishihama et al., 2005): emPAI $=10^{\mathrm{PAI}}-1$. The PAI index is obtained by dividing the observed peptides (taking into account the charge state and missed cleavages) of a specific protein in the analysis by the observable peptides. The observable peptides were determined by using the "MS Digest" software". The protein relative contents in each condition were calculated using the next equation, being $\mathrm{Mr}$ the protein molecular weight: Protein content (weight $\%)=($ emPAI x $\mathrm{Mr} / \Sigma$ (emPAI x $\mathrm{Mr}))^{*} 100$.

\section{RESULTS AND DISCUSSION}

A total of 413 proteins were identified under $\mathrm{BAC}$ and 611 under RFC. These proteins from both conditions were subjected to relative quantification through the EmPAI value identifying proteins more abundant in each condition (Table 1) and at last, only proteins related to the lack of fermentable carbon source were selected according to their phenotypes, GO Terms or references. Proteins average content were: 0,24 in BAC and 0,16 in RFC.

Specifically, 28 proteins were detected under BAC to be related with the lack of fermentable

Tab. 1. Number of proteins detected specifically in the biological aging condition (BAC) and in the reference fermentative condition (RFC), in both conditions, those detected in higher abundance in $\mathrm{BAC}(\mathrm{BAC}>\mathrm{RFC})$ and in $\mathrm{RFC}(\mathrm{RFC}>\mathrm{BAC})$ and with similar conditions (BAC $\approx \mathrm{RFC}$ ).

\begin{tabular}{cc}
\hline Type of counting & Nr proteins \\
\hline BAC specific & 206 \\
\hline RFC specific & 404 \\
\hline Both conditions & 207 \\
\hline BAC $>$ RFC & 65 \\
\hline RFC $<$ BAC & 45 \\
\hline BAC $\approx$ RFC & 97 \\
\hline
\end{tabular}

carbon source while 33 in RFC (Table 2). These values correspond to $6,8 \%$ and $5,4 \%$, in BAC and RFC, respectively. From the 28 BAC proteins, 24 were implicated in the biofilm formation biological process and in RFC, 28 out of 33. The rest of proteins (Asc1p, Mtl1p, Pof1p, Ssb1p, Ssb2p and Ste20p) are involved in the response to glucose starvation.

Most of the stress response proteins are localized in cytoplasm and organelles like mitochondria, nucleus and membrane; being the first of them known to play an important role under a condition such as BAC in terms of alternative carbon sources consumption and the formation of biofilm (Moreno-García et al., 2014). 9 lack of fermentable carbon source stress-proteins were detected in the analysis to be localized in the mitochondria: Tuf1p and Idh1p in the mitochondrial matrix; Idh1p, Qcr6p and Por1p in the mitochondrial intermembrane space; Idh $1 p$ and $\operatorname{Idh} 2 p$ in the mitochondrial isocitrate dehydrogenase complex, in the mitochondrial membrane, Idh1p and Pdb1p in the mitochondrial nucleoid, mitochondrial membrane part and $\operatorname{Pdb} 1 \mathrm{p}$ in mitochondrial pyruvate dehydrogenase complex; while Cpr3p, Ssa2p and Tdh1p are not known to be localized in a mitochondrial part specifically.

Also the majority shows molecular functions as ATP binding, nucleotide binding and cystathionine beta-synthase activity (intermediate step in the synthesis of cysteine) and are involved in biological processes beside those mentioned in the table 2 like oxidationreduction process, general response to stress, cytoplasmic translation, protein folding, biosynthesis of trehalose which constitutes a major reserve carbohydrate in Saccharomyces cerevisiae; and tricarboxylic acid cycle essential for the catabolism of two-carbon molecules together with the glyoxilate cycle and gluconeogenesis.

As it has been observed the number of proteins related to the stress was pretty similar, however proteins under the two conditions were not the same (Table 2 and Fig. 2): 14 proteins were detected under BAC and not under RFC 
Tab. 2. Proteins detected that participate in the response to the lack of fermentable carbon source.

\begin{tabular}{|c|c|c|c|c|c|c|}
\hline \multirow[t]{2}{*}{ Protein } & \multicolumn{2}{|c|}{$\begin{array}{l}\text { Presence in the } \\
\text { condition }\end{array}$} & \multirow{2}{*}{$\begin{array}{l}\text { Uniprot } \\
\text { entry }\end{array}$} & \multirow[t]{2}{*}{ Protein names } & \multirow[t]{2}{*}{ Subcellular location } & \multirow{2}{*}{$\begin{array}{l}\text { Biological } \\
\text { process }\end{array}$} \\
\hline & $\mathrm{BAC}$ & $\mathrm{RFC}$ & & & & \\
\hline Asc1p & $\mathrm{X}$ & $\mathrm{X}$ & P38011 & $\begin{array}{l}\text { Guanine nucleotide-binding protein subunit } \\
\text { beta-like protein (Receptor for activated C } \\
\text { kinase) (Receptor of activated protein kinase } \\
\text { C 1) (RACK1) }\end{array}$ & Cytoplasm. & \multirow{6}{*}{$\begin{array}{l}\text { Response } \\
\text { to glucose } \\
\text { starvation }\end{array}$} \\
\hline Mtl1p & $\mathrm{X}$ & & P53214 & Protein MTL1 (MID two-like protein 1) & $\begin{array}{l}\text { Membrane; Single- } \\
\text { pass type I membrane } \\
\text { protein. }\end{array}$ & \\
\hline Pof1p & & $\mathrm{X}$ & P25576 & Promoter of filamentation protein 1 & & \\
\hline Ssb1p & $\mathrm{X}$ & $\mathrm{X}$ & P11484 & $\begin{array}{l}\text { Heat shock protein SSB1 (Cold-inducible } \\
\text { protein YG101) }\end{array}$ & Cytoplasm. & \\
\hline Ssb2p & $\mathrm{X}$ & $\mathrm{X}$ & P40150 & Heat shock protein SSB2 & Cytoplasm. & \\
\hline Ste20p & & $\mathrm{X}$ & Q03497 & $\begin{array}{c}\text { Serine/threonine-protein kinase STE20 (EC } \\
\text { 2.7.11.1) }\end{array}$ & Cytoplasm. Nucleus. & \\
\hline Arg8p & & $\mathrm{X}$ & P18544 & $\begin{array}{l}\text { Acetylornithine aminotransferase, } \\
\text { mitochondrial (ACOAT) (EC 2.6.1.11) }\end{array}$ & $\begin{array}{l}\text { Mitochondrion } \\
\text { matrix. }\end{array}$ & \\
\hline Asc1p & $\mathrm{X}$ & $\mathrm{X}$ & P38011 & $\begin{array}{l}\text { Guanine nucleotide-binding protein subunit } \\
\text { beta-like protein (Receptor for activated C } \\
\text { kinase) (Receptor of activated protein kinase } \\
\text { C 1) (RACK1) }\end{array}$ & Cytoplasm. & \\
\hline $\operatorname{Atg} 11 p$ & $\mathrm{X}$ & $\mathrm{X}$ & Q12527 & $\begin{array}{c}\text { Autophagy-related protein } 11 \text { (Cytoplasm to } \\
\text { vacuole targeting protein 9) }\end{array}$ & $\begin{array}{c}\text { Preautophagosomal } \\
\text { structure membrane; } \\
\text { Peripheral } \\
\text { membrane protein. } \\
\text { Vacuole membrane; } \\
\text { Peripheral membrane } \\
\text { protein. }\end{array}$ & \\
\hline Ccw14p & $\mathrm{X}$ & $\mathrm{X}$ & 013547 & $\begin{array}{l}\text { Covalently-linked cell wall protein } 14 \text { (Inner } \\
\text { cell wall protein) }\end{array}$ & $\begin{array}{l}\text { Secreted > cell wall. } \\
\text { Membrane; Lipid- } \\
\text { anchor > GPI-anchor. }\end{array}$ & \\
\hline Coq5p & & $\mathrm{X}$ & P49017 & $\begin{array}{c}\text { 2-methoxy-6-polyprenyl-1,4-benzoquinol } \\
\text { methylase, mitochondrial (EC 2.1.1.201) } \\
\text { (Ubiquinone biosynthesis methyltransferase } \\
\text { COQ5) }\end{array}$ & Mitochondrion. & $\begin{array}{l}\text { Biofilm } \\
\text { formation }\end{array}$ \\
\hline Cox15p & & $\mathrm{X}$ & P40086 & $\begin{array}{l}\text { Cytochrome c oxidase assembly protein } \\
\text { COX15 }\end{array}$ & $\begin{array}{l}\text { Mitochondrion inner } \\
\text { membrane; Multi- } \\
\text { pass membrane } \\
\text { protein. }\end{array}$ & \\
\hline Cpr3p & $\mathrm{X}$ & $\mathrm{X}$ & P25719 & $\begin{array}{l}\text { Peptidyl-prolyl cis-trans isomerase C, } \\
\text { mitochondrial (PPIase C) (EC 5.2.1.8) } \\
\text { (Cyclophilin C) (PPI-III) (Rotamase C) }\end{array}$ & $\begin{array}{l}\text { Mitochondrion } \\
\text { matrix. }\end{array}$ & \\
\hline Cys4p & $\mathrm{X}$ & & P32582 & $\begin{array}{l}\text { Cystathionine beta-synthase (EC 4.2.1.22) } \\
\text { (Beta-thionase) (Serine sulfhydrase) (Sulfur } \\
\text { transfer protein 4) }\end{array}$ & & \\
\hline Hat2p & $\mathrm{X}$ & & P39984 & Histone acetyltransferase type B subunit 2 & Cytoplasm. Nucleus. & \\
\hline Hcr1p & & $\mathrm{X}$ & Q05775 & $\begin{array}{c}\text { Eukaryotic translation initiation factor } 3 \\
\text { subunit J (eIF3j) (Eukaryotic translation } \\
\text { initiation factor } 330 \mathrm{kDa} \text { subunit) (eIF-3 } 30 \\
\mathrm{kDa} \text { ) }\end{array}$ & Cytoplasm. & \\
\hline Hsp12p & $\mathrm{X}$ & $\mathrm{X}$ & P22943 & $\begin{array}{c}12 \mathrm{kDa} \text { heat shock protein (Glucose and } \\
\text { lipid-regulated protein) }\end{array}$ & & \\
\hline
\end{tabular}


Tab. 2. (continued) Proteins detected that participate in the response to the lack of fermentable carbon source.

\begin{tabular}{|c|c|c|c|c|c|c|}
\hline \multirow[t]{2}{*}{ Protein } & \multicolumn{2}{|c|}{$\begin{array}{l}\text { Presence in the } \\
\text { condition }\end{array}$} & \multirow{2}{*}{$\begin{array}{l}\text { Uniprot } \\
\text { entry }\end{array}$} & \multirow[t]{2}{*}{ Protein names } & \multirow[t]{2}{*}{ Subcellular location } & \multirow{2}{*}{$\begin{array}{c}\text { Biological } \\
\text { process }\end{array}$} \\
\hline & $\mathrm{BAC}$ & $\mathrm{RFC}$ & & & & \\
\hline Idh1p & $\mathrm{X}$ & & P28834 & $\begin{array}{l}\text { Isocitrate dehydrogenase [NAD] subunit } \\
1 \text {, mitochondrial (EC 1.1.1.41) (Isocitric } \\
\text { dehydrogenase) (NAD }(+) \text {-specific ICDH) }\end{array}$ & Mitochondrion. & \\
\hline Idh2p & $\mathrm{X}$ & & P28241 & $\begin{array}{l}\text { Isocitrate dehydrogenase [NAD] subunit } \\
2 \text {, mitochondrial (EC 1.1.1.41) (Isocitric } \\
\text { dehydrogenase) (NAD }(+) \text {-specific ICDH) }\end{array}$ & $\begin{array}{l}\text { Mitochondrion } \\
\text { matrix. }\end{array}$ & \\
\hline Lys20p & $\mathrm{X}$ & & P48570 & $\begin{array}{c}\text { Homocitrate synthase, cytosolic isozyme (EC } \\
2.3 .3 .14)\end{array}$ & Cytoplasm. & \\
\hline Pdb1p & $\mathrm{X}$ & $\mathrm{X}$ & P32473 & $\begin{array}{l}\text { Pyruvate dehydrogenase E1 component } \\
\text { subunit beta, mitochondrial (EC 1.2.4.1) } \\
\text { (Pyruvate dehydrogenase complex } \\
\text { component E1 beta) (PDHE1-B) }\end{array}$ & $\begin{array}{l}\text { Mitochondrion } \\
\text { matrix. }\end{array}$ & \\
\hline Pex1p & $\mathrm{X}$ & & P24004 & $\begin{array}{l}\text { Peroxisomal ATPase PEX1 (Peroxin-1) } \\
\text { (Peroxisomal assembly protein 1) } \\
\text { (Peroxisome biogenesis protein PAS1) }\end{array}$ & $\begin{array}{l}\text { Cytoplasm. } \\
\text { Peroxisome } \\
\text { membrane; } \\
\text { Peripheral membrane } \\
\text { protein; Cytoplasmic } \\
\text { side. }\end{array}$ & \\
\hline Por1p & $\mathrm{X}$ & & P04840 & $\begin{array}{l}\text { Mitochondrial outer membrane protein } \\
\text { porin } 1 \text { (Voltage-dependent anion-selective } \\
\text { channel protein 1) (VDAC-1) }\end{array}$ & $\begin{array}{l}\text { Mitochondrion outer } \\
\text { membrane. }\end{array}$ & \\
\hline Prb1p & & $\mathrm{X}$ & P09232 & $\begin{array}{l}\text { Cerevisin (EC 3.4.21.48) (Proteinase YSCB) } \\
\text { (Vacuolar protease B) (PrB) }\end{array}$ & Vacuole. & \\
\hline Pre9p & & $\mathrm{X}$ & P23638 & $\begin{array}{c}\text { Proteasome subunit alpha type-3 (EC } \\
\text { 3.4.25.1) (Macropain subunit Y13) } \\
\text { (Multicatalytic endopeptidase complex } \\
\text { subunit Y13) (Proteasome component Y13) } \\
\text { (Proteinase YSCE subunit 13) }\end{array}$ & Cytoplasm. Nucleus. & formation \\
\hline Pst2p & $\mathrm{X}$ & $\mathrm{X}$ & Q12335 & Protoplast secreted protein 2 & Secreted. & \\
\hline Qcr6p & $\mathrm{X}$ & $\mathrm{X}$ & P00127 & $\begin{array}{l}\text { Cytochrome b-c1 complex subunit } 6 \\
\text { (Complex III subunit 6) (Complex III subunit } \\
\text { VI) (Cytochrome c1 non-heme } 17 \mathrm{kDa} \\
\text { protein) (Mitochondrial hinge protein) } \\
\text { (Ubiquinol-cytochrome c reductase complex } \\
17 \mathrm{kDa} \text { protein) }\end{array}$ & $\begin{array}{l}\text { Mitochondrion inner } \\
\text { membrane. }\end{array}$ & \\
\hline $\operatorname{Rad} 23 p$ & $\mathrm{X}$ & $\mathrm{X}$ & P32628 & UV excision repair protein RAD23 & Nucleus. Cytoplasm. & \\
\hline Rad6p & $\mathrm{X}$ & & P06104 & $\begin{array}{c}\text { Ubiquitin-conjugating enzyme E2 } 2 \text { (EC } \\
\text { 6.3.2.19) (Radiation sensitivity protein 6) } \\
\text { (Ubiquitin carrier protein UBC2) (Ubiquitin- } \\
\text { protein ligase UBC2) }\end{array}$ & Cytoplasm. Nucleus. & \\
\hline Ras2p & & $\mathrm{X}$ & P01120 & Ras-like protein 2 & $\begin{array}{l}\text { Cell membrane; } \\
\text { Lipid-anchor. }\end{array}$ & \\
\hline Rhr2p & & $\mathrm{X}$ & P41277 & $\begin{array}{l}\text { Glycerol-1-phosphate phosphohydrolase } \\
1 \text { ((DL)-glycerol-3-phosphatase 1) (EC } \\
\text { 3.1.3.21) (Related to HOR2 protein 2) }\end{array}$ & Cytoplasm. Nucleus. & \\
\hline Rps7ap & $\mathrm{X}$ & $\mathrm{X}$ & P26786 & 40S ribosomal protein S7-A (RP30) (RP40) & $\begin{array}{l}\text { Cytoplasm. Nucleus > } \\
\text { nucleolus. }\end{array}$ & \\
\hline
\end{tabular}


Tab. 2. (continued) Proteins detected that participate in the response to the lack of fermentable carbon source.

\begin{tabular}{|c|c|c|c|c|c|c|}
\hline \multirow[t]{2}{*}{ Protein } & \multicolumn{2}{|c|}{$\begin{array}{l}\text { Presence in the } \\
\text { condition }\end{array}$} & \multirow{2}{*}{$\begin{array}{l}\text { Uniprot } \\
\text { entry }\end{array}$} & \multirow[t]{2}{*}{ Protein names } & \multirow[t]{2}{*}{ Subcellular location } & \multirow{2}{*}{$\begin{array}{l}\text { Biological } \\
\text { process }\end{array}$} \\
\hline & $\mathrm{BAC}$ & $\mathrm{RFC}$ & & & & \\
\hline Rrg7p & & $\mathrm{X}$ & Q08774 & $\begin{array}{l}\text { Required for respiratory growth protein } 7, \\
\text { mitochondrial }\end{array}$ & Mitochondrion. & \\
\hline Sec $28 p$ & & $\mathrm{X}$ & P40509 & $\begin{array}{l}\text { Coatomer subunit epsilon (Epsilon-coat } \\
\text { protein) (Epsilon-COP) }\end{array}$ & $\begin{array}{c}\text { Cytoplasm. Golgi } \\
\text { apparatus membrane; } \\
\text { Peripheral membrane } \\
\text { protein; Cytoplasmic } \\
\text { side. Cytoplasmic } \\
\text { vesicle > COPI-coated } \\
\text { vesicle membrane; } \\
\text { Peripheral membrane } \\
\text { protein; Cytoplasmic } \\
\text { side. }\end{array}$ & \\
\hline See1p & & $\mathrm{X}$ & P40516 & $\begin{array}{l}\text { N-lysine methyltransferase SEE1 (EC 2.1.1.-) } \\
\text { (Secretion and early endocytosis protein 1) }\end{array}$ & Cytoplasm. & \\
\hline Ssa2p & $\mathrm{X}$ & $\mathrm{X}$ & P10592 & Heat shock protein SSA2 & $\begin{array}{l}\text { Cytoplasm. Secreted > } \\
\text { cell wall. }\end{array}$ & \\
\hline Sti1p & & $\mathrm{X}$ & P15705 & Heat shock protein STI1 & Cytoplasm. & \\
\hline Tdh1p & $\mathrm{X}$ & $\mathrm{X}$ & P00360 & $\begin{array}{c}\text { Glyceraldehyde-3-phosphate dehydrogenase } \\
1 \text { (GAPDH 1) (EC 1.2.1.12) }\end{array}$ & Cytoplasm. & \\
\hline Tfs $1 p$ & $\mathrm{X}$ & & P14306 & $\begin{array}{c}\text { Carboxypeptidase Y inhibitor (CPY inhibitor) } \\
\text { (CDC25 suppressor 1) (I(C)) (Ic) (Protein } \\
\text { DKA1) (Protein NSP1) }\end{array}$ & Cytoplasm. & $\begin{array}{l}\text { Biofilm } \\
\text { formation }\end{array}$ \\
\hline Tom70p & & $\mathrm{X}$ & P07213 & $\begin{array}{l}\text { Mitochondrial import receptor subunit } \\
\text { TOM70 (70 kDa mitochondrial outer } \\
\text { membrane protein) (Translocase of outer } \\
\text { membrane } 70 \text { kDa subunit) }\end{array}$ & $\begin{array}{l}\text { Mitochondrion outer } \\
\text { membrane; Single- } \\
\text { pass membrane } \\
\text { protein. }\end{array}$ & \\
\hline Tps1p & & $\mathrm{X}$ & Q00764 & $\begin{array}{c}\text { Alpha,alpha-trehalose-phosphate synthase } \\
\text { [UDP-forming] } 56 \mathrm{kDa} \text { subunit (EC } \\
\text { 2.4.1.15) (General glucose sensor subunit } \\
\text { 1) (Glycogen metabolism control protein } \\
\text { GLC6) (Trehalose synthase complex catalytic } \\
\text { subunit TPS1) (Trehalose-6-phosphate } \\
\text { synthase) (UDP-glucose-glucosephosphate } \\
\text { glucosyltransferase) }\end{array}$ & Cytoplasm. & \\
\hline Tps2p & $\mathrm{X}$ & & P31688 & $\begin{array}{c}\text { Trehalose-phosphatase (EC 3.1.3.12) } \\
\text { (Trehalose synthase complex catalytic } \\
\text { subunit TPS2) (Trehalose-6-phosphate } \\
\text { phosphatase) (TPP) }\end{array}$ & Cytoplasm. & \\
\hline Tuf1p & $\mathrm{X}$ & & P02992 & Elongation factor $\mathrm{Tu}$, mitochondrial (tufM) & Mitochondrion. & \\
\hline Ycr051wp & & $\mathrm{X}$ & P25631 & Ankyrin repeat-containing protein YCR051W & & \\
\hline Yfr018cp & & $\mathrm{X}$ & P43599 & Uncharacterized protein YFR018C & & \\
\hline Ygp1p & $\mathrm{X}$ & & P38616 & Protein YGP1 (GP38) & Secreted. & \\
\hline
\end{tabular}


while 18 were detected under RFC and not under BAC. Proteins detected only in BAC or with more abundance under this condition were: Mtl1p, Ccw14p, Cpr3p, Cys4p, Hat2p, Idh1p, Idh2p, Lys20p, Pex1p, Por1p, Qcr6p, Rad6p, Rps7Ap, Tdh1p, Tfs1p, Tps2p, Tuf1p and Ygp1p.

All of them unless Mtl1p participate in the biofilm formation biological process. Mtl1p was only found in BAC with a protein content of 0,29 (Fig. 2). This protein is a putative plasma membrane sensor involved in cell integrity signaling and stress response during glucose starvation and oxidative stress through TOR1 and RAS2 inhibition (Petkova et al., 2010), whose protein presence were not reported under BAC.

The rest of the BAC proteins besides being involved in the biofilm formation participate also in processes like oxidation-reduction process (Idh1p, Idh2p, Tdh1p and Qcr6p), tricarboxylic acid cycle (Idh1p and Idh2p) or chromatin silencing at telomere (Hat2p and Rad6p). Ccw14p or covalently-linked cell wall protein 14 detected

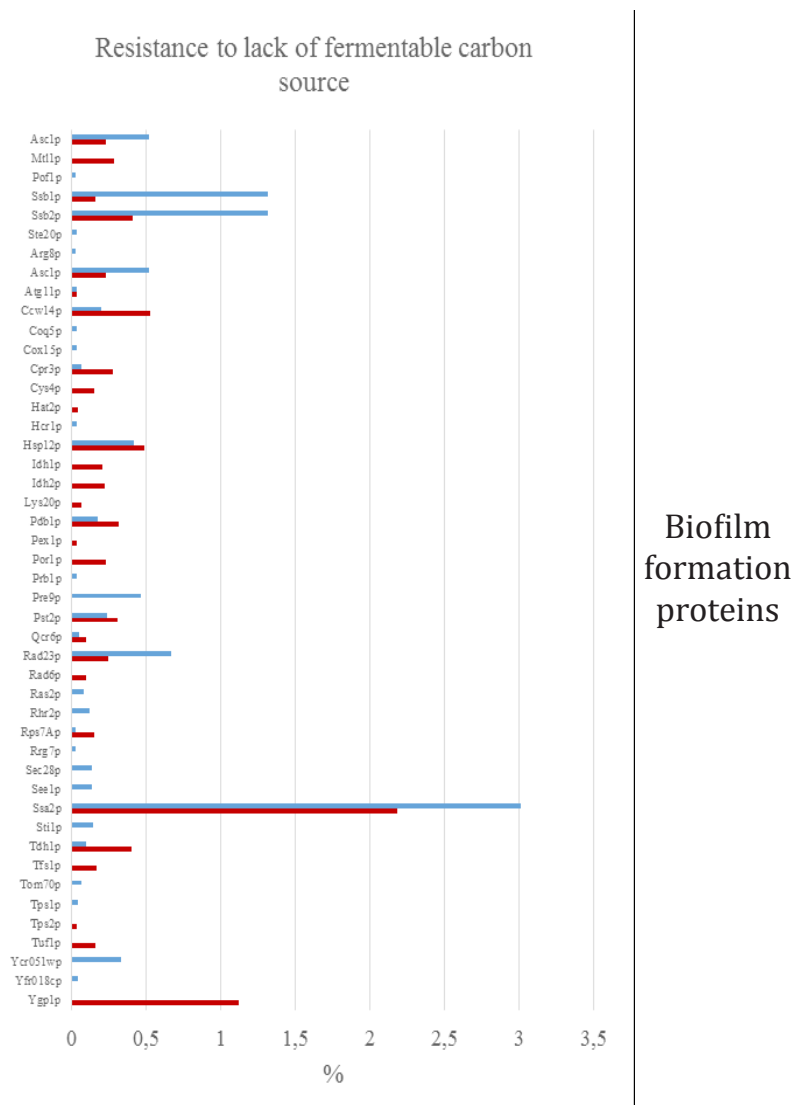

Fig. 2. Proteins involved in the response to lack of fermentable carbon. Biological aging condition (BAC) protein quantity is represented in red while reference fermentative condition (RFC) is shown in blue. in a higher content under BAC, up to 2.68-fold higher than under RFC, is a component of the inner layer of the cell wall which as the same time could be found in the extracellular region. This protein is extensively 0-glycosylated and its presence might be relevant for the cell wall hydrophobicity which at the same time contributes to the yeast buoyancy and biofilm formation (Zara et al., 2012). Meanwhile, the heat shock protein Hsp12p may play a role in a switch from carbohydrate utilizing metabolism to fatty acid utilizing metabolism at the same time that in cell adhesion (Zara et al., 2002) and it is known to be induced by glucose starvation and by fatty acids (Stone et al, 1990).

Proteins like Ygp1p and Ssa2p were detected under BAC in a very high quantity if related to the relative quantity average which is 0,24 in BAC. The first of them reaching 1,12 and not detected under $\mathrm{RFC}$ is an extracellular protein involved in the cellular amino acid metabolic process and in the yeast cell wall assembly. Vandenbosch et al. (2013) observed a reduced biofilm formation in YGP1 null mutants. These two facts may shed importance to the this gene in order to do further genetic and phenotypic analyses and further produce yeast strains with enhanced velum formation. The second one, Ssa2p, with a 2,18 protein content and up to 3,01 in RFC, is a cytoplasmic protein or could be found in the cell wall that participates in the response to stress and protein folding biological processes.

\section{CONCLUSION}

As a conclusion, it can be said that a similar number of proteins were identified in the flor yeast Saccharomyces cerevisiae G1 under a biological aging condition and under reference fermentative condition to be involved in the response to the lack of fermentable carbon source. Most of them participates in the biofilm forming condition. A sensor protein, Mtl1p, involved in stress response during glucose starvation was only detected under the medium lacking a fermentable carbon source and biofilm formation proteins Ygp1p and Ssa2p were found highly expressed under this condition.

This study together with other experiments that definitively confirm the necessity of these proteins synthesis, may lead to the genetic improvement of flor yeast strains aimed to enhance their survival during the biological aging process and hence the whole wine elaboration process. 
Acknowledgments. Spain's Ministry of Economy and Competitiveness and the European Community (FEDER), Grant RTA2011-00020-C02-02, MINECOINIA-CCAA.

\section{REFERENCES}

1. Alexandre, H. (2013). Flor yeasts of Saccharomyces cerevisiae-Their ecology, genetics and metabolism. Int. J. Food Microbiol, 167: 269-275.

2. Bradford, M.M. (1976). A rapid and sensitive method for the quantitation of microgram quantities of protein utilizing the principle of protein-dye binding. Anal. Biochem. 72: 248-254.

3. Fidalgo, M., Barrales, R. R., Ibeas, J. I. and Jimenez, J. (2006). Adaptive evolution by mutations in the FLO11 gene. PNAS, 103: 11228-11233.

4. Fierro-Risco, J. Rincón, A. M., Benítez, T. and Codón, A. C. (2013). Overexpression of stress-related genes enhances cell viability and velum formation in Sherry wine yeasts. Appl. Microbiol. Biot. 97: 6867-6881.

5. Ishihama, Y., Oda, Y., Tabata, T., Sato, T., Nagasu, T., Rappsilber, J. and Mann, M. (2005). Exponentially modified protein abundance Index (emPAI) for estimation of absolute protein amount in proteomics by the number of sequenced peptides per protein. Mol. Cell. Proteomics, 4.9: 1265-1272.

6. Moreno-García, J., García-Martínez, T., Moreno, J., Millán, M.C., Mauricio, J.C. (2014). A proteomic and metabolomic approach for understanding the role of the flor yeast mitochondria in the velum formation. Int. J. Food Microbiol. 172: 21-29.

7. Peinado, R. A. and Mauricio, J. C. (2009). Biologically aged wines, p. 81-103. In: Moreno-Arribas, M.V., Polo, M.C. (Eds.), Wine Chemistry and Biochemistry. Springer.
8. Petkova, M.I., Pujol-Carrion, N., Arroyo, J., Garcia-Cantalejo, J. and Angeles de la Torre-Ruiz, M. (2010). Mtl1 is required to activate general stress response through Tor1 and Ras2 inhibition under conditions of glucose starvation and oxidative stress. J. Biol. Chem. 285: 19521-19531.

9. Pretorius, I. S. and Bauer, F. F. (2002). Meeting the consumer challenge through genetically customized wine-yeast strains. Trends Biotechnol. 20: 426-432.

10. Stone, R. L., Matarese, V., Magee, B. B., Magee, P. T., Bernlohr, D. A. (1990) Cloning, sequencing and chromosomal assignment of a gene from Saccharomyces cerevisiae which is negatively regulated by glucose and positively by lipids. Gene 96:171-176.

11. Vandenbosch, D., De Canck, E., Dhondt, I., Rigole, P., Nelis, H. J., Coenye, T. (2013) Genomewide screening for genes involved in biofilm formation and miconazole susceptibility in Saccharomyces cerevisiae. FEMS Yeast Res. 13: 720-730.

12. Zara, S., Farris, A. G., Budroni, M., Bakalinsky, A. T. (2002) HSP12 is essential for biofilm formation by a Sardinian wine strain of S. cerevisiae. Yeast, 2002, 19: 269-276.

13. Zara, G., Goffrini, P., Lodi, T., Zara, S., Mannazzu, I., Budroni, M. (2012) FL011 expression and lipid biosynthesis are required for air-liquid biofilm formation in a Saccharomyces cerevisiae flor strain. FEMS yeast research, 12: 864-866.

14. Zara, G., Zara, S., Pinna, C., Marceddu, S. and Budroni, M. (2009). FL011 gene length and transcriptional level affect biofilm-forming ability of wild flor strains of Saccharomyces cerevisiae. Microbiology, 155: 3838-3846.

15. Zara, S., Gross, M. K., Zara, G., Budroni, M. and Bakalinsky, A. T. (2010). Ethanol-independent biofilm formation by a flor wine yeast strain of Saccharomyces cerevisiae. Appl. Environ. Microb. 76: 4089-4091. 


\title{
Rinsing Device for Separating Seeds of the Species from the Solanaceae Botanical Family
}

\author{
Paweł NOWICKI, Roman HOŁUBOWICZ*) \\ Poznań University of Life Sciences, Faculty of Horticulture and Landscape Architecture, Department of \\ Plant Pathology, Seed Science and Technology. Poland \\ *)corresponding author, e-mail: rhseed@au.poznan.pl
}

BulletinUASVM Horticulture 72(1) / 2015

Print ISSN 1843-5254, Electronic ISSN 1843-5394

DOI:10.15835/buasvmcn-hort:10975

\begin{abstract}
In the years 2013-2014, the research was carried out to develop a new rinsing device for separating seeds of the species from the Solanaceae botanical family. At first, the design was done, then, the prototype of wood was constructed. The machine was tested on the tomato seeds of the cultivar Frodo $\mathrm{F}_{1}$ in the Polish seed company breeding tomatoes. The device allowed to increase seed germination in both series of trials. In case on cleaning seeds with the flesh, the seed germination in the best fraction improved from $56.2 \%$ (check) to $79.4 \%$. In the case of the seeds only (without flash), the seeds germination improved in the best fraction from $63.2 \%$ (check) to 92 $\%$. In both cases, it was due to lowering to amount of abnormal seedlings. Better quality of the graded seeds was followed by heavier seeds. The device needs further testing on the seeds of other cultivars and species.
\end{abstract}

Keywords: seed fractions, seed quality grading, seed rinsing, tomato seed production

\section{INTRODUCTION}

Production of seeds of high quality requires a large amount of work and often specialized equipment (Szpakowska, Hołubowicz 2012 ). The first step of processing takes place already in the field when the harvesting is done (Copeland, McDonald 1985). The processed seeds should be dry and healthy (Domoradzki, Korpal 2004). Seed cleaning can be divided into 3 stages: primary, basic and individual. The first one includes removing the biggest and heaviest impurities, whereas the basic one uses the same set of machines for different species of seeds. Individual seeds cleaning focuses on selected characters of a given species in order to clean them up to required quality standard, e.g. colour or shape (George 1985; Kelly, George1998).

Tomato has been the most important vegetable species in the world (FAO 2014). Every year, in the world, there are about 33 million tons of tomato fruits produced, i.e. $10 \%$ of the total area of all vegetable species (Bocian 2006). In 2014, there was an increase in this production to almost 39 million tons (Anonymous 2014). Production of tomato fruits in Poland also increased from 312
(2000) to 760 thousand tons (2012) (FAOstat 2014). This large production needs both good cultivars and seeds. Tomato seeds, before they go on sale, require additional processing and conditioning work (George 1985; Kelly, George 1998). At first, they must be extracted from the fruit pulp. To do so, it is necessary to ferment the pulp with seeds. The pulp with the seeds is then rinsed with water. Seed companies use special machines for it. The whole process consists of three steps: fermentation, the rinsing the pulp with water and centrifugation to remove water and residues (Demir 1994). This method effectively separates the seeds from the pulp but further processes require drying the seeds. Seed companies breeding tomato and producing its seeds have been looking for new devices to minimize the time and cost of production and maximize profits (Hołubowicz, Cieślik 2005). Such devices will not only lower the costs of tomato seeds production, but should also improve the final seed quality.

The objective of this experiment was to design, build and test a rinsing device for separating seeds of the species from the Solanaceae botanical family while improving the quality of seeds. 